\title{
VERSLO RIZIKOS VALDYMAS IR JO TOBULINIMAS
}

\author{
Laura Kaleininkaitè1, Ingrida Trumpaitè2 \\ Vilniaus Gedimino technikos universitetas, Sauletekio al. 11, LT-10223 Vilnius, Lietuva \\ El.paštas: ${ }^{1}$ laura.kaleininkaite@vv.vgtu.lt; ${ }^{2}$ ingrida.trumpaite@vv.vgtu.lt
}

Iteikta 2007-02-08; priimta 2007-04-28

\begin{abstract}
Santrauka. Verslo rizikos valdymas i̇monių veikloje yra labai svarbus procesas, suteikiantis pranašumą, siekiant dirbti efektyviau ir norint išlikti konkurencinèje kovoje, užtikrinantis palankius veiklos rezultatus. Tačiau Lietuvos įmonėse rizikos valdymas - vis dar didele problema. Lietuvoje visuose ekonomikos sektoriuose susiduriama su daugeliu verslo rizikos rūšių, tačiau jos valdomos nepakankamai. Verslo rizikai valdyti straipsnyje siūloma praktiškai naudoti tikimybinius skirstinius, leidžiančius prognozuoti finansinius įmonès veiklos rezultatus, o verslo rizikos valdymui tobulinti siūlomas integruotas rizikos valdymo modelis, kuris atspindi šių dienų sparčiai besikeičiančią ekonomiką bei ekonomikos subjektu poreiki minimaliomis sąnaudomis užtikrinti neriboto skaičiaus rizikos rūšiu valdymą.
\end{abstract}

Reikšminiai žodžiai: verslo rizika, verslo rizikos valdymas, neapibrěžtumas, prognozavimas, tikimybinis skirstinys, rizikos valdymo modelis.

\section{BUSINESS RISK MANAGEMENT AND ITS IMPROVEMENT}

\author{
Laura Kaleininkaité丶 ${ }^{1}$ Ingrida Trumpaité2 \\ Vilnius Gediminas Technical University, Saulètekio al. 11, LT-10223 Vilnius, Lithuania \\ E-mail: ${ }^{l}$ laura.kaleininkaite@vv.vgtu.lt; ${ }^{2}$ ingrida.trumpaite@vv.vgtu.lt
}

Received 8 February 2007; accepted 28 March 2007

\begin{abstract}
Business risk management is a very important process in any company. It helps to gain advantage over competitors and to work more effectively. Still, in Lithuanian companies risk management is quite a big problem. In Lithuania we face many different kinds of risk in all sectors of economy, but these risks are not suitably managed. In this article we propose to practically use probability distributions for the business risk management, allowing to forecast the future financial results of a company, and for the improvement of business risk management we present integrated risk management model, which reflects nowadays changing economy and the need to ensure the management of different risks at the minimal cost.
\end{abstract}

Keywords: business risk, business risk management, uncertainty, forecasting, probability distribution, risk management model.

\section{Ivadas}

Rinkos ekonomikos sąlygomis dirbančių i̇monių veikla yra labai dinamiška, todèl neišvengiamai sietina su rizika. Kintant aplinkai, verslui būdingas neapibrèžtumas, prognozuojamų rezultatų neužtikrintumas, rizikingi sprendimai. Todėl, keičiantis rinkos sąlygoms bei intensyvèjant konkurencijai, išauga poreikis valdyti riziką. Menka rizikos val- dymo patirtis dinamiškoje konkurencinejje rinkoje lemia nepakankamai pagristus sprendimus ir gali daryti neigiamą itaką imonių veiklos rezultatyvumui. Todèl rizikos valdymas Lietuvos verslininkams tampa ypač aktualus, siekiant ne tik išlikti, bet ir sėkmingai veikti dinamiškoje rinkoje.

Lietuvoje rizikos įvertinimas, prognozavimas bei valdymas - kol kas per mažai dėmesio sulaukiantis ekonomi- 
kos aspektas tiek iš verslininkų, tiek iš valstybinių institucijų, susijusių su verslo plètra. Neigiamos nevaldomos rizikos poveikio pasekmès vis skaudžiau jaučiamos ne tik finansų veikloje, bet ir daugelyje kitų visuomenès gyvenimo sričių. Rizikos visiškai išvengti neįmanoma, taigi būtina tinkamai ją valdyti.

Riziką galima valdyti, tai yra naudoti i̇vairias priemones, leidžiančias tam tikru laipsniu prognozuoti rizikingo ivvykio îvykimą ir imtis priemonių rizikos laipsniui mažinti [1]. Verslo rizikos valdymas - tai jau ne pasyvus nusiteikimas rizikuoti, o metodų ir priemonių visuma aktyviai veikti ateitị ir gauti minimalų nuokrypị nuo laukiamų rezultatų. Tai priemonių rengimo ir realizavimo procesas, kurio tikslas - sumažinti galimas neigiamas nepalankiu ivvykiu pasekmes realizuojant priimtą sprendimą [2].

Straipsnio tikslas - pateikti praktinio tikimybinių skirstinių pritaikymo finansiniams įmonès veiklos rezultatams prognozuoti, atsižvelgiant ì galimybių neapibrèžtumą, galimybes, bei pasiūlyti integruotą rizikos valdymo modelị verslo rizikos valdymui tobulinti.

\section{Rizikos vertinimas tikimybiniais skirstiniais}

Ūkinei ir finansinei rizikai kiekybiškai įvertinti siūloma ìvairių metodų. Vieno ar kito metodo taikymą lemia turima informacija, reikalaujamas rezultatų tikslumas. Rizikos vertinimas naudojant tikimybinius skirstinius yra veiksmingas, nes jis leidžia nustatyti sąveiką tarp rezultatus veikiančių kintamujuc ir tiksliau numatyti norimus rezultatus. Tikimybiniu skirstiniu išreikštas rezultatas neapsiriboja tik vienu ateities variantu, kaip kad būtų gavus rezultatą, išreikštą konkrečiu skaičiumi, bet leidžia įvertinti įvairias ateities būsenas, pamatyti, kokia yra tikimybė viršyti laukiamą rezultatą ar jo nepasiekti, stebèti, kaip kintant rezultatams kinta rizika, išreikšta vidutiniu kvadratiniu nuokrypiu.

Tyrime buvo naudoti konkrečios imonès duomenys. Imonès finansinès būsenos ir jų raidos tendencijos yra nusakomos pagrindiniais finansiniais dokumentais (ataskaitomis) - balansine ataskaita, pelno (nuostolio) ataskaita, pelno paskirstymo ataskaita, pinigu srautų ataskaita, todèl galima subjekto finansų projektavimą griststi šių dokumentų parengimu. Tyrime naudojamas parengtas pagrindinis imonès biudžeto projektas ir nagrinèjami pagrindiniai jo elementai. Tyrime atliekama grynojo pelno tikimybinio pasiskirstymo galimybių prognozė 2006 m., atsižvelgiant į riziką ir neapibrèžtumą. Ši prognozė aprašoma tarpusavyje susietų prekès vieneto kainos, pardavimo apimčių rodiklių galimybių tikimybès skirstiniais.

Grynojo pelno rodiklis svyruoja todèl, kad neimanoma vienareikšmiškai nusakyti šio parametro. Geriausia, ką galima padaryti, tai nusakyti visas pagrindines šio parametro kitimo alternatyvas, kartu įvertinant kiekybines šių alternatyvų charakteristikas - jų tikimybes. Nors realybejje pasireikš tik viena iš šių alternatyvų, tačiau šiandieniai valdy- mo metodai leidžia pasirinkti sprendimus, optimizuojančius tikètinuosius rezultatus.

Tyrime naudojami analizès ir prognozavimo principai remiasi prielaida, kad kaip ir veiksmuose, kai naudojamasi tik vienareikšmiais dydžiais, taip ir veiksmuose su finansiniais rodikliais, kurie priimami kaip atsitiktiniai dydžiai, galioja ta pati matematinių veiksmų ir prognozavimo logika.

Atliktas tyrimas įrodo, kad planuojant įmonès finansus, reikia ịvertinti riziką ir situacijos neapibrèžtumą bei poveiki galutiniams veiklos rezultatams.

Pagal gautas pardavimo kainas, kiekius ir grynojo pelno prognozès rodiklius gauname įmonès veiklos rezultatu ir finansinę būseną nusakančių rodiklių galimybių tikimybès skirstinius.

Tirti imami rodikliai - prekès vieneto kaina, pardavimo apimtis Lt, grynasis pelnas Lt, iš balanso ir pelno (nuostolio) ataskaitos stochastiniai dydžiai charakterizuojami juc vidurkiais ir standartiniais nuokrypiais. Šios charakteristikos nusako šių rodiklių galimybių tikimybès skirstinius.

Ivertinus prekès numatomą užimti rinkos dalị, nustatoma būsima prekès kaina ir galimas nuokrypis nuo numatytos kainos.

Prekès vieneto kainu galimybiu modelis yra normalusis skirstinys $N(200 ; 6)$ (žr. 1 pav.). Kainos pasiskirstymo vidurkis $M=200,17$, o vidutinis kvadratinis nuokrypis $\sigma=$ 6,044 (kitimo intervalą suskaidome $3 \mathrm{Lt}$ padalomis). Specializuota programa STATISTICA 5.0 gauname normaluji skirstini. Remiantis trijų sigma taisykle, i intervalą $\pm 3 \sigma$ (tai yra $[178 ; 221]$ ) telpa 99,7 \% visų galimų reikšmių. Vadinasi, minimali reikšmè būtų $178 \mathrm{Lt}$, o maksimali - $221 \mathrm{Lt}$. Tačiau gauti šias kraštutines reikšmes yra labai maža tikimybè, o parduoti prekę už labiausiai tikètiną vertę - $202 \mathrm{Lt}$ yra $38 \%$ tikimybè.

Pardavimo litais galimybių skirstinys yra N(1 934 577; 112 605). Pardavimo apimties pasiskirstymo vidurkis $M=$ 1934 577, o vidutinis kvadratinis nuokrypis $\sigma=112605$. Su STATISTICA 5.0 randame normaluji skirstini (žr. 2 pav.). Pardavimo apimties intervalas yra [1 553 609; 2374 092].

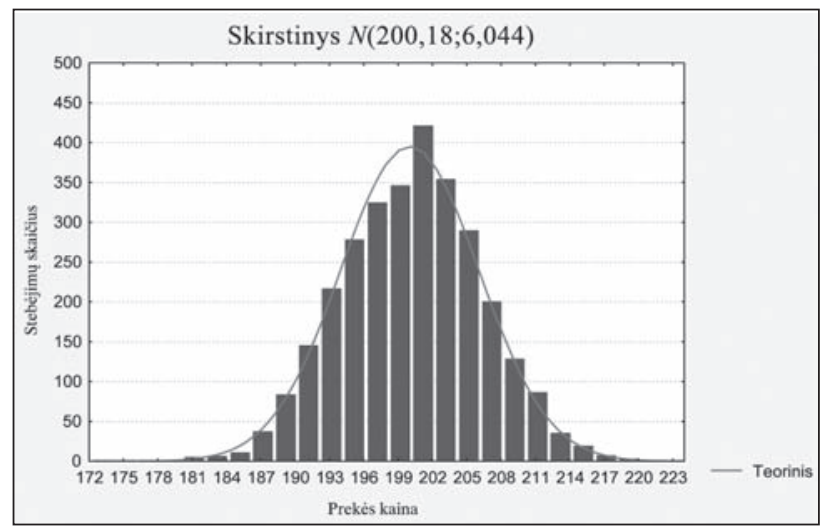

1 pav. Prekès vieneto kainos skirstinys

Fig 1. Item price distribution 
Labiausiai tikètinas pardavimo apimties intervalas yra [1 $900000 ; 2000$ 000] su $40 \%$ tikimybe, o kad bus pasiekta pardavimo iš intervalo [1 $800000 ; 2000000]-65 \%$ tikimybè.

Grynojo pelno galimybių modelis yra tai pat normalusis skirstinys $N(96$ 391; 57 918) (žr. 3 pav.). Grynojo pelno vidurkis yra $M=96391$, o vidutinis kvadratinis nuokrypis $\sigma=57$ 918. Grynojo pelno intervalas yra [-137 386; 285 498]. Patirti nuostolių ar gauti maksimalų pelną labai maža tikimybè, gauti vidutinę labiausiai tikètiną reikšmę $96391 \mathrm{Lt}$ yra $25 \%$ tikimybè. Gauti rezultatą iš intervalo [60 000; 180000$]$ galima su $76 \%$ tikimybe, o iš intervalo [40 000; 200 000] - su $87 \%$ tikimybe. Kadangi pagal standartinį nuokrypi sprendžiame apie riziką, bus sumažinta prekès vieneto kainos rizika, t. y. standartinis nuokrypis, ir tokiu būdu išnagrinèta, kaip tai paveiks pardavimo apimtis ir grynaji pelną.

Prekès vieneto kainos galimybiu modelis yra normalusis skirstinys $N(200 ; 2)$. Kainos pasiskirstymo vidurkis $M=199,97$, o vidutinis standartinis nuokrypis $\sigma=2$ (kitimo intervalą suskaidome $1 \mathrm{Lt}$ padalomis). Su STATISTICA 5.0 randame normaluji skirstini (4 pav.). Remiantis tri-

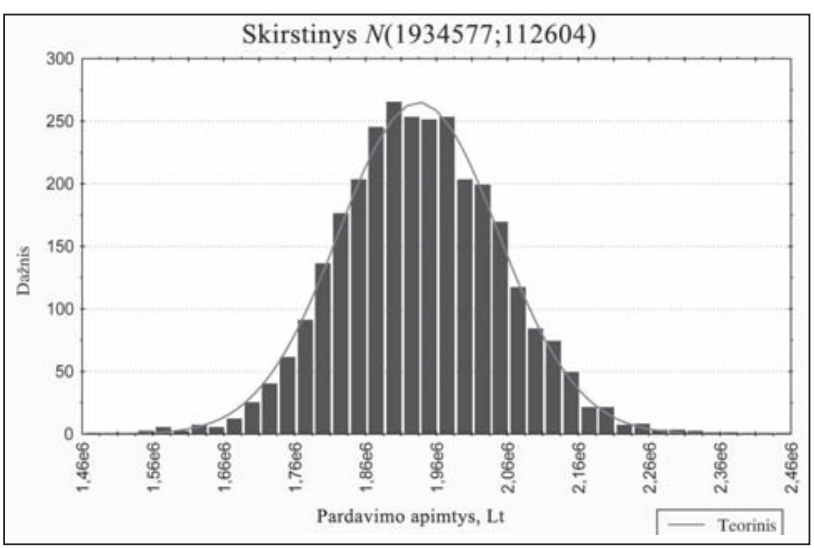

2 pav. Pardavimo apimčiu galimybių skirstinys

Fig 2. Sales possibilities distribution

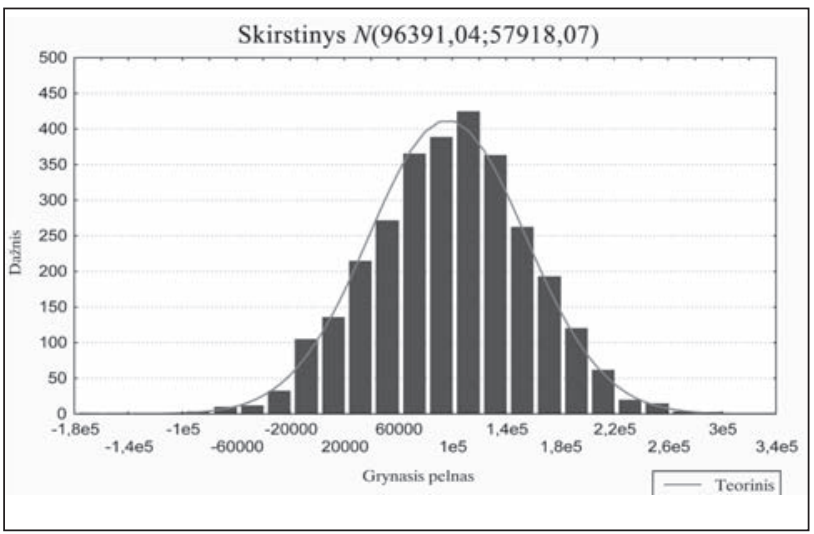

4 pav. Prekès vieneto kainos skirstinys

Fig 4. Unit price distribution jų sigma taisykle, i i intervalą $\pm 3 \sigma$ (tai yra [193; 207]) telpa 99,7 \% visu galimų reikšmių. Vadinasi, minimali reikšmė būtų 193 Lt, o maksimali - 207 Lt. Tačiau gauti šias kraštutines reikšmes yra labai maža tikimybè, o labiausiai tikètinos prekès vieneto kainos reikšmės yra $200 \mathrm{Lt}$ ir $201 \mathrm{Lt}$, jas galima gauti su $38 \%$ tikimybe. Gauti rezultatą iš intervalo [198; 202] tikimybè yra $77 \%$. Palyginę 1 ir 4 pav. matome, kad 4 paveiksle kainos reikšmių išsibarstymas labai sumažèjo, vadinasi, sumažèjo ir kainos rizika.

5 pav. pardavimų litais galimybių skirstinys yra N(1 934 211; 99 257,4). Matome, kad sumažèjus kainos standartiniam nuokrypiui, mažejja ir pardavimo apimčiu standartinis nuokrypis. Palyginus 2 ir 5 pav. akivaizdu, kad 5 pav. reikšmių išsibarstymas sumažèja. Galima gauti vidutini, labiausiai tikètiną pardavimo apimčiu kieki 1920000 Lt su 44 \% tikimybe. Pardavimo apimtys iš intervalo [1 $850000 ; 2035000]$ bus pasiektos su $71 \%$ tikimybe.

Grynojo pelno galimybiu modelis yra normalusis skirstinys $N(96379 ; 30$ 965) (6 pav.). Šio skirstinio minimali reikšmé būtų 0 Lt, o maksimali - 200000 Lt. Taigi sumažèjus kainos rizikai, sumažeja didesnio grynojo pelno ga-

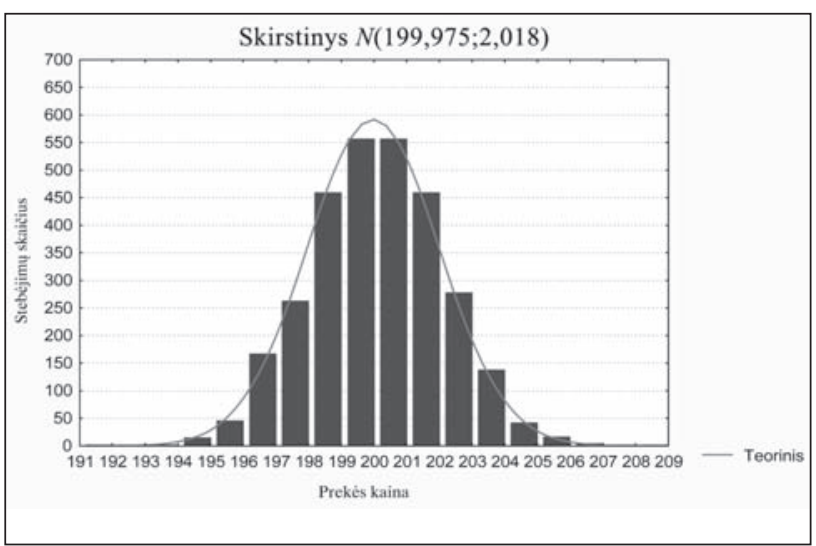

3 pav. Grynojo pelno galimybių skirstinys

Fig 3. Net profit possibilities distribution

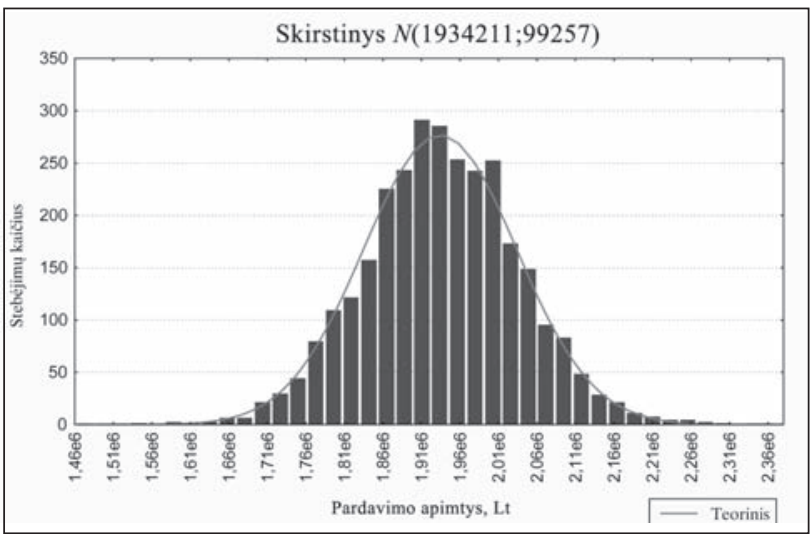

5 pav. Pardavimo apimčiu galimybių skirstinys

Fig 5. Sales possibilities distribution 
vimo galimybès, tačiau sumažèja ir nuostolių tikimybè. Gauti dažniausiai pasikartojančią reikšmę - 110000 Lt yra 13 \% tikimybè. Grynasis pelnas iš intervalo [80 000; 140000 ] bus gautas su $73 \%$ tikimybe.

Kuo didesnis laukiamos reikšmés nuokrypis, tuo didesné rizika, kad gali nepasitvirtinti laukiamas pelnas. Atliktas tyrimas rodo, kad galima rinktis ar parduoti prekę didesne kaina su didesne rizika ir gauti didesni grynaji pelną, ar parduoti prekę su mažesne kainos rizika ir gauti mažesni grynaji pelną. Pasirinkus pirmaji varianta, atsiranda ir didesnè rizika patirti nuostolių. Antruoju atveju nuostolių tikimybè yra labai maža.

\section{Verslo rizikos valdymo tobulinimas}

Verslo rizikos valdymui tobulinti pateikiamas integruotas verslo rizikos valdymo modelis. Šis metodas siejamas su įmonès strategija, darbuotojais, procesais, technologijomis ir žiniomis. Visi įmonès veiklos procesai, lemiantys tam tikrą rizika, yra sujungiami ir vertinami kaip visuma.

Pirmiausia įmonès veikla analizuojama strateginiu lygmeniu - taip pasireiškia integruotas požiūris ị i̇monès veiklos procesus. Vèliau veiklos procesai analizuojami diferencijuotai, t. y. valdant riziką akcentuojamos atskiros, akivaizdžios rizikos rūšys, su kuriomis i̇monè susiduria savo veikloje. Integruotas imonès rizikos valdymo modelis pateiktas 7 paveiksle.

Modelio schemą galima būtų apibūdinti taip:

1. Sprendimai priimami strateginiu lygmeniu - išanalizavus įmonés veiklos modeli, numatomi tiksliniai imonès veiklos procesai, turintys lemiamą itaką veiklos tęstinumui.

2. Šie tiksliniai veiklos procesai analizuojami diferencijuotai - taip išaiškinama galima nevaldoma rizika, atsirandanti veikiant šiems verslo procesams.

3. Identifikuotos rizikos įvertinamos pagal jų reikšmingumą ir ivvykio tikimybę.

4. Tik reikšmingiausioms ir labiausiai tikètinoms rizikos rūšims valdyti skiriami riboti imonès ištekliai.

Atsižvelgiant i aprašytaji modeli, i̇monès veiklos procesus reikètų nagrinėti riziką paskirstant i aplinkos rizika, procesu rizika, informacijos, reikalingos sprendimams priimti, riziką.

Aplinkos rizika atsiranda dèl išorinių jègų poveikio. Šios jẻgos galètų labai pakeisti esmines prielaidas, kuriomis remiantis formuluojami pagrindiniai imonès tikslai bei strategijos ir išskirtiniais atvejais grèsti imonès išlikimui $[3,4]$.

Aplinkos rizika pasireiškia nesugebejjimu suprasti vartotojų poreikių, laiku ir efektyviai reaguoti i konkurentų veiksmus, per dideliu priklausymu nuo lengvai pažeidžiamų tiekejjų ir pan.

Procesų rizika atsiranda tuomet, kai įmonès veiklos procesai neužtikrina, kad įmonès tikslai bus pasiekti. Taip atsitinka dèl neteisingai sukurtų ir blogai valdomų imonès

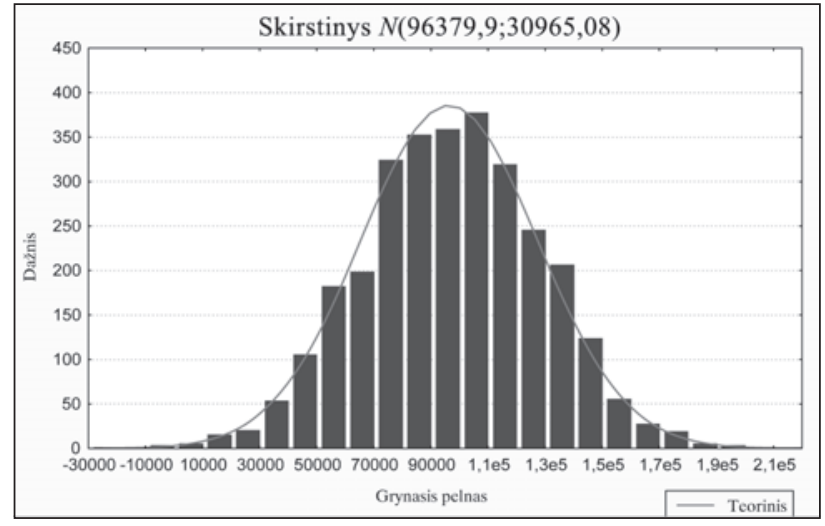

6 pav. Grynojo pelno skirstinys

Fig 6. Net profit distribution

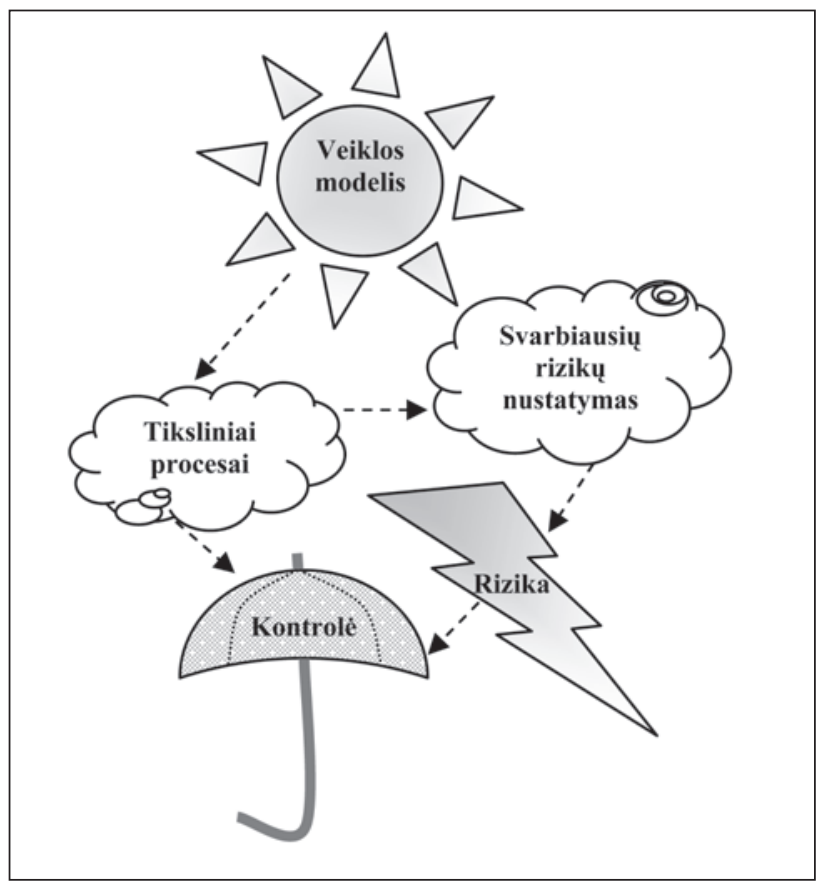

7 pav. Integruotas įmonès rizikos valdymo modelis

Fig 7. Integrated company‘s risk management model

veiklos procesų. Veiklos rizika - procesas, nesuderintas su verslo strategija, nepatenkina klientų poreikių arba yra neefektyvus. Šios rūšies rizika pasireiškia esant netinkamiems verslo strategijai igyvendinti žmogiškiesiems ištekliams, esant žinių kapitalo trūkumui, taip pat ir neefektyviai veikiančiam produktų tobulinimo procesui, netinkamai veiklos ciklo trukmei ir pan. $[5,6]$.

Igaliojimų rizika - nepatenkinami sprendimų prièmimo rezultatai dèl neaiškios ir neadekvačios atsakomybès bei atskaitomybès įmonès veiklos procese. Kitaip tariant, netinkamai numatyti igaliojimai ir atsakomybe, o del to sprendimų rezultatai gali būti klaidingi ar netinkami konkrečioje situacijoje [7].

Vientisumo rizika - informacijos apdorojimo (technologiju) rizika - procese naudojamos informacinès technologijos neveikia, kaip tikètasi, arba neužtikrina duomenų 
gavimo laiku, patikimumo, saugumo [8]. Klastotès ir neteisèti veiksmai padaro žalą organizacijos reputacijai arba procesas neužtikrina svarbaus finansinio, intelektinio arba fizinio turto saugumo, neapsaugo nuo neteisingo ar neteisèto šio turto naudojimo.

Finansiné rizika - procesas neefektyviai valdo kainos, likvidumo, kredito rizikas.

Imonès veikla priklauso nuo informacijos, naudojamos sprendimams priimti, kokybés. Sprendimų prièmimo informacijos rizika atsiranda tuomet, kai informacija, kuria remiantis priimami strateginiai, veiklos ir finansiniai sprendimai, yra nepatikima arba netinkama.

Sprendimų prièmimo informacijos rizika pasireiškia tiek strateginiu i̇monès veiklos lygmeniu - vertinant aplinkos itaką imonès verslui bei formuojant i̇monès strategiją, kuriant verslo modeli, vertinant versla, skirstant išteklius, planuojant, tiek procesų valdymo arba taktiniu i̇monés veiklos lygmeniu $[1,4,5]$. Priimant finansinius sprendimus, taip pat susiduriama su šia rizika. Finansinių sprendimų prièmimo rizika pasireiškia planuojant būsimus veiklos rezultatus, sudarant imonès biudžetą, vertinant investicijas.

Jei veiklos vertinimo kriterijai ir kita verslo informacija, kuria naudojamasi priimant verslo sprendimus, yra nepatikima ar netinkama, ja ir nebus naudojamasi iš viso, arba ji skatins netinkamą elgseną.

Integruotas rizikos valdymo modelis atspindi šių dienų sparčiai besikeičiančios ekonomikos bruožus bei klasikini ekonomikos subjektų poreikị minimaliomis sąnaudomis užtikrinti neriboto skaičiaus rizikos rūšių valdymą. Būtent šiu dienu ekonomikos specifika lemia neribotai dideli galimu rizikos rūšiu skaičių ir itin kritines rizikos nevaldymo pasekmes. Atsižvelgiant į šiuolaikines pasaulines tendencijas ir politinès, socialinès, technologinès bei kitokio pobūdžio raidos ir pažangos procesų vystymąsi bei šiu procesų spartèjima, išryškèja naujos reikšmingos priežastys rizikai atsirasti. Lietuvai pamažu integruojantis i Vakaru pasaulio ekonomika, tampant jos subjektu, Lietuvoje esančių organizacijų veiklą vis labiau veikia įvairūs procesai toli už šalies ribu.

Reikètu prisiminti, kad verslo rizikos valdymas neturi baigtinio tikslo, tai yra atsinaujinantis ir nuolat modifikuojamas procesas, atsižvelgiant ị vidinius aplinkos ir įmonès pokyčius.

Pasiūlyto metodo igyvendinimas padètų Lietuvos įmonèms realiai vertinti kilusias rizikos problemas ne tik vidaus, bet ir tarptautinès rinkos mastu, pasirinkti efektyviausias priemones verslo rizikoms valdyti ir tobulinti. Imonès, noredamos igyvendinti ši modeli, turi rengti rizikos valdymo strategijas, analizuoti savo pagrindinius veiklos procesus, identifikuoti jų funkcionavimo efektyvuma, numatyti galimas rizikas, parengti planus, kaip jas valdyti, bei užtikrinti kontrolès mechanizmą.

\section{Išvados}

1. Verslo dalyviu pasirinkimas rizikuoti ar nerizikuoti priklauso nuo daugybès aplinkybių. Suprantama, jog be verslo dalyvių rizikos, kaip ir be konkurencijos, verslas negali būti efektyvus. Vadinasi, verslo efektyvumas lemia rizikingus verslininkų veiksmus bei sprendimus. Todèl verslo rizikos valdymas yra aktuali teorinè ir praktinè problema.

2. Ūkinès ir finansinès rizikos kiekybiniam ịvertinimui siūlomas rizikos vertinimas tikimybiniais skirstiniais. Šis rizikos analizès metodas leidžia tirti įmonès finansų prognozes, atsižvelgiant $\mathfrak{i}$ ateities laukiamų veiksnių ir priklausančių nuo jų rezultatų kintamumą. Jis veiksmingas, nes leidžia nustatyti sąveiką tarp rezultatus veikiančių kintamuju ir tiksliau numatyti norimus rezultatus. Tikimybiniu skirstiniu išreikštas rezultatas neapsiriboja tik vienu ateities variantu, bet leidžia įvertinti įvairias ateities būsenas, pamatyti, kokia yra tikimybe viršyti laukiamą rezultatą, ar jo nepasiekti, stebėti, kaip kintant rezultatams, kinta rizika, išreikšta vidutiniu kvadratiniu nuokrypiu.

3. Prognozuojant įmonès grynaji pelną ir imant jị veikiančius rodiklius ne kaip tiksliai apibrěžtus skaičius, o kaip tikimybinius skirstinius, galima sumažinti riziką bei neapibrèžtumą, kadangi:

- prognozuodami negalime numatyti tiksliu rezultatuc, kurie atsiras vienu ar kitu momentu;

- skirstiniais yra ivertinama su grynuoju pelnu susijusi rizika;

- skirstiniai leidžia pamatyti grynojo pelno pasiskirstymo spektrą, detaliai išanalizuoti visas galimas grynojo pelno reikšmes.

4. Pritaikius tikimybinių skirstinių metodą praktiškai ir išanalizavus gautus rezultatus, buvo įsitikinta, kad didèjant rizikai, grynojo pelno tikimybė mažèja, o galimų nuostolių tikimybė didèja.

5. Lietuvos įmonès, praktiškai pritaikiusios integruota verslo rizikos valdymo modeli, galètų realiai vertinti kilusias rizikos problemas, pasirinkti efektyviausias priemones verslo rizikai valdyti. Šiuo metu Lietuvos imonėms, prisidedančioms prie tarptautinio verslo plètros, rizikos valdymas tampa viena iš pagrindinių užduočių. Imonès, parengusios rizikos valdymo strategiją, išanalizavusios savo pagrindinius veiklos rezultatus, identifikavusios rizikos rūšis, parengusios planus kaip jas valdyti, pajègs gerokai sumažinti galimų nuostolių tikimybę.

\section{Literatūra}

1. SMITHSON, Ch.; SIMKINS, B. J. Does risk management add value? A survey of the evidence. Journal of Applied Corporate Finance, 2005, Vol 17, Issue 3, p. 8-17.

2. BEASLEY, M. S.; CLUNE, R.; Hermanson, D. R. Enterprise risk management: An empirical analysis of factors associated with the extent of implementation. Journal of Accounting and Public Policy, 2005, Vol 24, Issue 6, p. 521-531. 
3. FEHLE, F.; TSYPLAKOV, S. Dynamic risk management: Theory and evidence. Journal of Financial Economics, 2005, Vol 78, Issue 1, p. 3-47.

4. ROSENBERG, J. V.; SCHUERMANN, T. A general approach to integrated risk management with skewed, fat-tailed risks. Journal of Financial Economics, 2006, Vol 79, Issue 3, p. 569-614.

5. CULP, Ch. L. The Risk Management Process: Business Strategy and Tactics. Canada: John Wiley \& Sons, 2001. 624 p.
6. FLANAGON, R.; NORMAN, O. Risk management and Construction. London: Oxford, 1999. 200 p.

7. LINK, P.; MARXT, Ch. Integration of risk- and chance management in the co-operation process. International Journal of Production Economics, 2004, Vol 90, Issue 1, p. 71-78.

8. CROUHY, M.; MARK, R.; GALAI, D. Risk Management. McGraw-Hill, 2000. 752 p.

Laura KALEININKAITE். Doctoral student of Vilnius Gediminas Technical University, Department of Financial Engineering. Research interests: risk management, business value determination problems and business value management.

Ingrida TRUMPAITE். Doctoral student of Vilnius Gediminas Technical University, Department of Financial Engineering. Research interests: value and risk management, risk diversification problems, modelling of insurance companies development. 